\title{
Evaluation of the relationship between milk glutathione peroxidase activity, milk composition and various parameters of subclinical mastitis under seasonal variations
}

\author{
Hatice E. Colakoglu' ${ }^{1}$, Ozlem Kuplulu ${ }^{2}$, Mehmet R. Vural ${ }^{1}$, \\ Sukru Kuplulu ${ }^{1 *}$, Murat O. Yazlik' ${ }^{1}$ Ibrahim M. Polat ${ }^{3}$, Burcu Oz ${ }^{1}$, \\ Ufuk Kaya ${ }^{4}$, and Rustem Bayramoglu ${ }^{5}$ \\ ${ }^{I}$ Department of Obstetrics and Gynecology, Faculty of Veterinary Medicine, University of Ankara, \\ Ankara, Turkey \\ ${ }^{2}$ Department of Food Hygiene and Technology, Faculty of Veterinary Medicine, University of Ankara, \\ Ankara, Turkey \\ ${ }^{3}$ Department of Obstetrics and Gynecology, Faculty of Veterinary Medicine, University of Kirikkale, \\ Kirikkale, Turkey \\ ${ }^{4}$ Department of Biostatistics, Faculty of Veterinary Medicine, University of Ankara, Ankara, Turkey \\ ${ }^{5}$ Veterinary Medicine, Farm Animal Managament Practicer, Western Thrace, Greece
}

COLAKOGLU, H. E., O. KUPLULU, M. R. VURAL, S. KUPLULU, M. O. YAZLIK, I. M. POLAT, B. OZ, U. KAYA, R. BAYRAMOGLU: Evaluation of the relationship between milk glutathione peroxidase activity, milk composition and various parameters of subclinical mastitis under seasonal variations. Vet. arhiv 87 , 557-570, 2017.

\section{ABSTRACT}

The aims of this study were to evaluate the Glutathione peroxidase (GSH-Px) activity in milk, and various milk parameters [milk fat, milk protein, milk solids non-fat (SNF), somatic cell count (SCC), total bacteria count (TBC), electrical conductivity (EC)] in healthy dairy cows during lactation, and to demonstrate the significant correlations between GSH-Px activity, milk composition, SCC, TBC and EC under seasonal variations. The cows calving in January were assigned into the winter group $(n=30)$ while the other cows calving in August were assigned into the summer group $(\mathrm{n}=30)$. Milk samples were collected weekly during lactation, and monthly average values of the parameters were determined. Although milk GSH-Px activity was variable during lactation, it was significantly higher in the winter group compared to the summer group of cows during the first five months of lactation $(\mathrm{P}<0.001)$. However, between the $6^{\text {th }}$ and $10^{\text {th }}$ months of lactation, GSHPx activity was significantly higher in the summer group $(\mathrm{P}<0.001)$. In both groups of cows, GSH-Px activity was negatively correlated with SCC, TBC and EC during lactation. No correlation was found between GSH-Px

\footnotetext{
*Corresponding author:
}

Prof. Dr. Sukru Kuplulu, Department of Obstetrics and Gynecology, Faculty of Veterinary Medicine, University of Ankara, 06110, Diskapi/Altindag Ankara/ Turkey, E-mail: sukrukuplulu@gmail.com 
H. E. Colakoglu et al.: Glutathione peroxidase activity, milk composition and various parameters of subclinical mastitis

activity and milk composition. In conclusion, the alteration of milk GSH-Px levels could be used as a diagnostic tool for monitoring udder health due to its relationship with the parameters of subclinical mastitis. Furthermore, cows calving in winter had higher GSH-Px activity than those calving in summer, especially during the first few months of lactation. These findings indicate that milk GSH-Px activity in cows during lactation could be influenced by seasonal variations.

Key words: cow, milk, glutathione peroxidase, subclinical mastitis, season

\section{Introduction}

Oxidative stress, characterised by an increased production of free radicals and decreased antioxidant defense, is the result of an imbalance between oxidant and antioxidant mechanisms (SORDILLO and AITKEN, 2009; KONVICNA et al., 2015). Oxidants lead to damage to the biological macromolecules of cells, and disruption of normal metabolism and physiology. These alterations in cells lead to metabolic disorders and diseases in dairy cows (PILARCZYK et al., 2012; KUROKAWA et al., 2016). Antioxidant concentrations and levels of free radicals are predictive of determining oxidative stress in cows. Detection of antioxidant enzymes may be helpful in the health management of cows (YANG and LI, 2015). Therefore, detection of the antioxidant enzymes in milk has been used in evaluating the oxidative status and udder health of dairy cows (ANDREI et al., 2011). It has been reported that decreased antioxidant activity affects the immune system and phagocytic activity of cells and thereby increases the incidence of mastitis and puerperal disease (HAYAJNEH, 2014). Mastitis is a disease that affects a large number of dairy cows. As well as affecting production and profitability, mastitis has a major welfare impact. It is very important to determine mastitis early,-using various techniques (ABD ELLAH, 2013). Both clinical and subclinical mastitis are associated with increased free radicals and decreased antioxidants in milk (ATAKISI et al., 2010).

Antioxidant activity is produced by antioxidant enzymes (Glutathione peroxidase, catalase, superoxide dismutase) and certain vitamins. Glutathione peroxidase (GSH-Px) is a selenocysteine-containing protein that plays an important role in the cellular defence against oxidative stress (KANKOFER et al., 2010). However, GSH-Px, as an indicator of oxidative stress, catalyzes the reduction of various hydrogen and lipid peroxides (CELI, 2011). It is also capable of preserving milk lipids from oxidation (ABD ELLAH et al., 2013). GSH-Px activity depends on the stage of lactation (PILARCZYK et al., 2012), species and diet (FOX and KELLY, 2006). A decrease in GSH-Px activity in mastitis related to inflammation has been defined (ATROSHI et al., 1987).

In dairy cows, high and low ambient temperature may affect their welfare, metabolism, production and reproduction (BERNABUCCI et al., 2002; TURK et al., 2015). Climatic changes also influence milk composition and some parameters of subclinical mastitis such as total bacteria count (TBC), somatic cell count (SCC), electrical conductivity (EC) 
H. E. Colakoglu et al.: Glutathione peroxidase activity, milk composition and various parameters of subclinical mastitis

(BERTOCCHI et al., 2014). However, high ambient temperature has been found to induce free radical production. Decreased antioxidant enzyme activity during the summer months has been reported in several studies, while levels of antioxidant and oxidant enzymes in blood have been used to analyze the relationship between heat stress and oxidant levels (BERNABUCCI et al., 2002; SAKATANI et al., 2012; TURK et al., 2015), but studies based on milk samples are missing.

The aims of this study were to evaluate the milk GSH-Px activity and various milk parameters (milk fat, milk protein, SNF, SCC, TBC, EC) in healthy dairy cows during lactation, and to demonstrate the significant correlations between GSH-Px activity, milk composition, $\mathrm{SCC}, \mathrm{TBC}$ and $\mathrm{EC}$, under seasonal variations.

\section{Materials and methods}

Animals and study design. The present study was conducted at a commercial dairy farm in Western Thrace $\left(41^{\circ} 8^{\prime} 11^{\prime \prime} \mathrm{N}, 2^{\circ} 52^{\prime} 57^{\prime \prime} \mathrm{E}\right)$ with 60 Holstein cows housed in free stall resting barns. All animals were fed a mixed ad libitum ration containing grass, corn silage and commercial concentrate twice a day. Cows were milked by an automatic milking system, twice daily. Average milk production for the herd was $9300 \pm 65 \mathrm{~kg} / 305$ days (between $5463 \pm 52$ to $13799 \pm 76 \mathrm{~kg} / 305$ days). The age of all the animals enrolled in the study ranged from 3 to 6 years. All cows were pregnant and free from disease.

Table 1. Temperature-humidity indexes (THI) during the study period

\begin{tabular}{|l|c|l|c|}
\hline \multicolumn{2}{|c|}{ Winter } & \multicolumn{2}{c|}{ Summer } \\
\hline Months & THI & Months & THI \\
\hline January & 46.22 & August & 79.54 \\
\hline February & 49.08 & September & 67.33 \\
\hline March & 54.15 & October & 60.63 \\
\hline April & 58.85 & November & 52.74 \\
\hline May & 64.44 & December & 48.43 \\
\hline June & 70.90 & January & 45.92 \\
\hline July & 73.36 & February & 48.13 \\
\hline August & 79.54 & March & 53.23 \\
\hline September & 67.33 & April & 59.50 \\
\hline October & 60.63 & May & 62.57 \\
\hline
\end{tabular}

The animals were divided into two groups according to calving season. The cows calving in January were assigned into the winter group $(n=30)$, while the other cows calving in August were assigned into the summer group $(\mathrm{n}=30)$. The temperaturehumidity index (THI) values were calculated using the equation: THI $(t, r h)=(1.8 \times$ 
H. E. Colakoglu et al.: Glutathione peroxidase activity, milk composition and various parameters of subclinical mastitis

$t+32)-(0.55-0.0055 \times r h) \times(1.8 \times \mathrm{t}-26)$, where: $t$ is ambient temperature in ${ }^{\circ} \mathrm{C}, r h$ is relative humidity as a percentage (RAVAGNOLO et al., 2000). The mean temperaturehumidity index (THI) during the study is shown in Table 1.

Sample collection and laboratory analysis. Teat end cleaning with ethanol $70 \%$ was performed before discarding the foremilk. $10 \mathrm{~mL}$ milk samples obtained weekly in sterile tubes during lactation were also collected from each quarter before morning milking, once a week. The samples were stored at $4{ }^{\circ} \mathrm{C}$. Monthly average values of the parameters were determined. Cows with evidence of clinical mastitis during a ten month period were excluded from the study.

Determination of GSH-Px activity was performed from skimmed milk with a commercial kit (Ransel, Randox Laboratories) and semiautomatic biochemistry analyzer (ERBA XL 600). The method described by PAGLIA and VALENTINE (1967) and GSH-Px activity was expressed as U/g protein. Milk samples were centrifuged at $3000 \mathrm{rpm}$ for 15 min, and the supernatant was used for the analysis of GSH-Px activity.

Milk fat, milk protein, milk solids non fat (SNF) and electrical conductivity were determined using a milk analyzer (Lactoscan MCC, Boeckel Co, Hamburg, Germany). The analysis of milk samples for somatic cell count and total bacteria count were performed using the flow cytometry technique in Bactocount equipment $\left(\mathrm{IBC}_{\mathrm{m}}\right.$, Bentley Instrument, Chaska, USA). The results of SCC and TBC were expressed as cells $/ \mathrm{mL}$ of milk and the number of colony forming units $/ \mathrm{mL}$ of milk (CFU/mL), respectively. The aAnalysis of all milk samples was evaluated by a different investigator.

Statistical analysis. Before performing the statistical analysis, data were examined for normality as parametric test assumptions. Descriptive statistics for each variable were calculated and presented as "Mean \pm Standart Error of Mean". The Pearson correlation coefficient was used to determine the correlation between GSH-Px and milk composition, SCC, TBC and EC. To test the differences in each parameter between time sampling in the winter and summer groups, General Linear Models with repeated measures design were used. When a significant difference was revealed, any significant terms were compared by Simple effect analysis with the Bonferroni adjustment. $\mathrm{P}<0.05$ was considered as significant in all analyses. SPSS ${ }^{\circledR}$ for Windows 14.1 (Licence No: 9869264) was used in the analysis of the data.

\section{Results}

In the summer group of cows, THI was higher than 72 in August, while in winter cows it was higher than 72 on July and August.

GSH-Px activity changed over time in both groups of cows $(\mathrm{P}<0.001)$. The GSH-Px levels ranged from 1.03 to $1.25 \mathrm{U} / \mathrm{g}$ protein in the winter group, while ranging from 0.97 to $1.25 \mathrm{U} / g$ protein in the summer group during the study (Fig. 1). GSH-Px activity was 
H. E. Colakoglu et al.: Glutathione peroxidase activity, milk composition and various parameters of subclinical mastitis

significantly higher in the winter group compared to the summer group during the first five months of lactation $(\mathrm{P}<0.001)$. However, between the $6^{\text {th }}$ and $10^{\text {th }}$ months of lactation, GSH-Px activity was significantly higher in the summer group of cows $(\mathrm{P}<0.001)$.

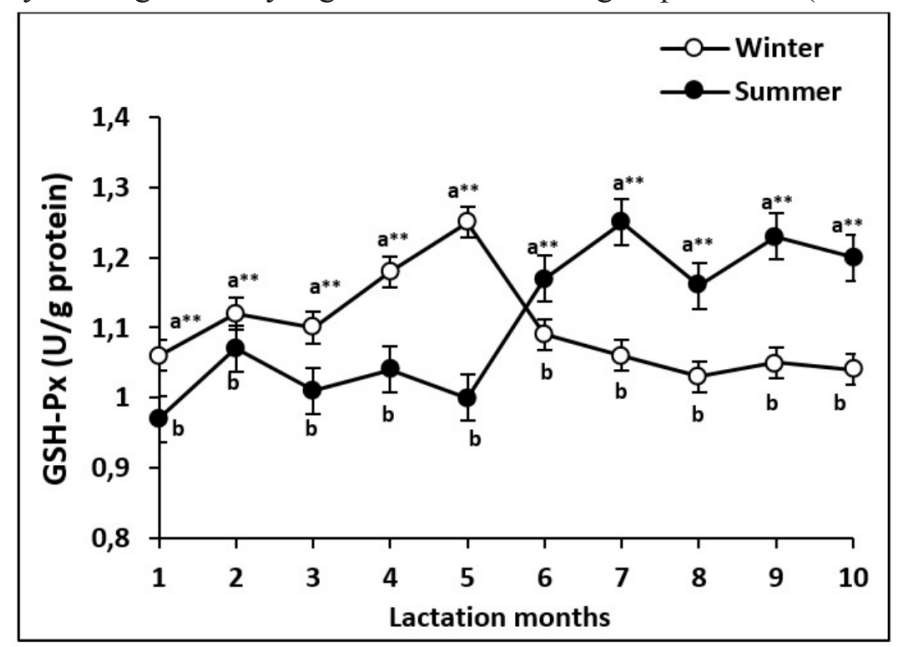

Fig. 1. Graphics showing the GSH-Px activity changes (mean \pm SEM) for the winter and summer groups of cows. Values with different superscripts $(\mathrm{a}, \mathrm{b})$ at the same sampling time were significantly different. (Winter; 1: January, 2: February, 3: March, 4: April, 5: May, 6: June, 7: July, 8: August, 9: September, 10: October. Summer; 1: August, 2: September, 3: October, 4:

November, 5: December, 6: January, 7: February, 8: March, 9: April, 10: May).

The milk SCC, TBC, EC, SNF, milk fat and protein also changed over time in both groups of cows $(\mathrm{P}<0.001)$. The milk $\mathrm{SCC}$ was significantly higher in the summer group in the $1^{\text {st }}, 3^{\text {rd }}$ and $5^{\text {th }}$ months of lactation (Fig. 2a). However, the SCC was significantly higher in the winter group compared to the summer group of cows between the $5^{\text {th }}$ and $10^{\text {th }}$ months of lactation. The TBC in the summer group of cows was significantly higher than in the winter group of cows in the first 7 months of lactation. However, TBC was significantly higher in the winter group between the $7^{\text {th }}$ and $10^{\text {th }}$ months of lactation (Fig. $2 \mathrm{~b})$. The EC was significantly higher in the summer group between the $2^{\text {nd }}$ and $5^{\text {th }}$ months of lactation. After the $5^{\text {th }}$ month, the milk EC was markedly higher in the winter group compared to the summer group of cows in the $6^{\text {th }}, 7^{\text {th }}$ and $9^{\text {th }}$ months of lactation (Fig. 2c).

Fat percentage was significantly higher in the winter group during the first 2 months of lactation. However, the summer group of cows had a higher fat percentage between the $5^{\text {th }}$ and $10^{\text {th }}$ months of lactation (Fig. 2d). The protein percentage was markedly higher in the winter group during the first 2 months of lactation (Fig. 2e). The summer group 
H. E. Colakoglu et al.: Glutathione peroxidase activity, milk composition and various parameters of subclinical mastitis

of cows had a higher protein percentage between the $5^{\text {th }}$ and $10^{\text {th }}$ months of lactation, excluding the $9^{\text {th }}$ month. Milk SNF percentage was significantly higher in the winter group of cows in the $1^{\text {st }}, 2^{\text {nd }}$ and $4^{\text {th }}$ months of lactation. However, the SNF percentage was markedly higher in the summer group of cows between the $6^{\text {th }}$ and $10^{\text {th }}$ months (Fig. $2 \mathrm{f}$ ).

The correlations between the milk GSH-Px activity and milk composition and some parameters of subclinical mastitis under seasonal variations are shown in Table 2.
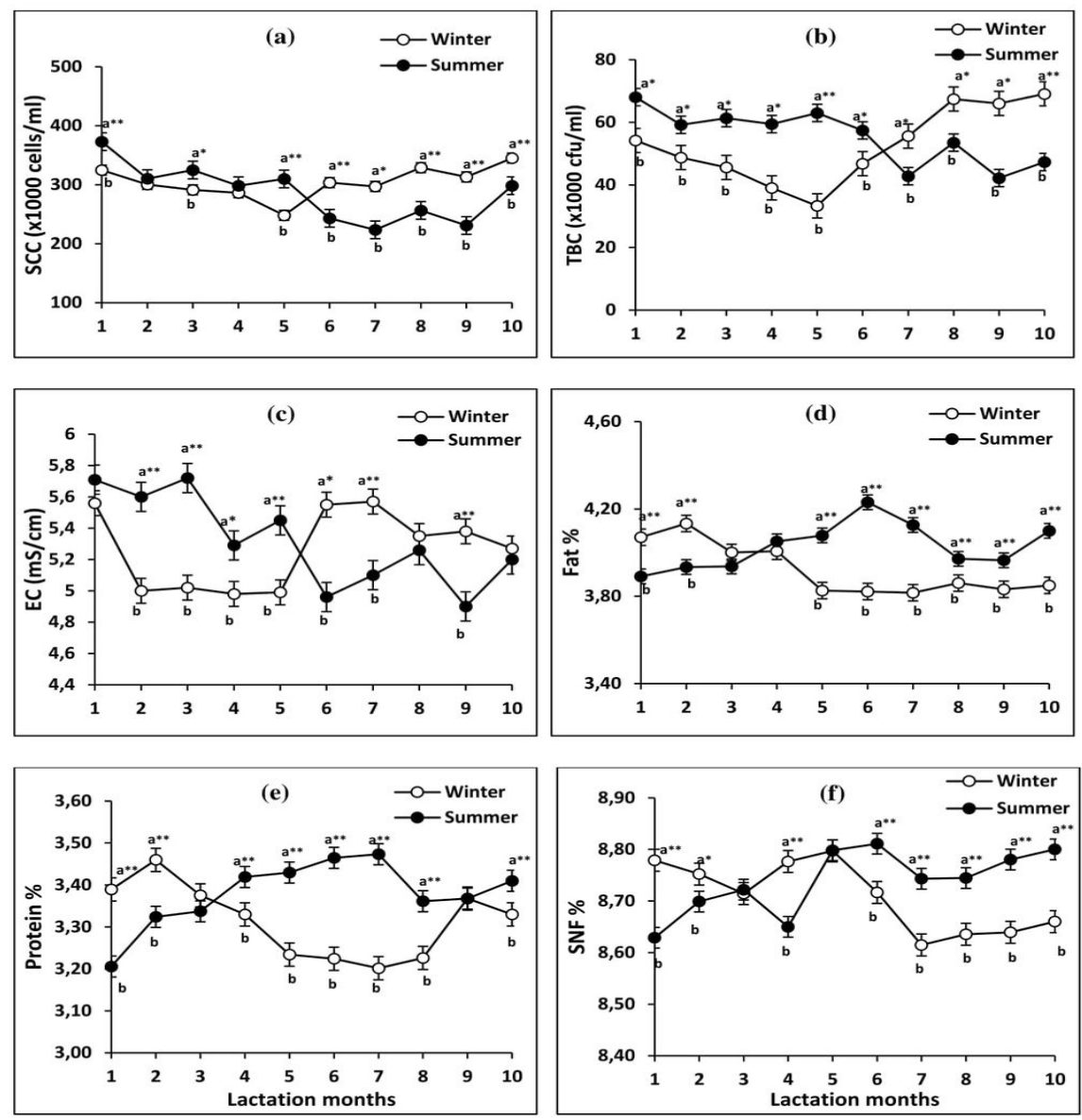

Fig. 2. Graphics showing the milk SCC (a), TBC (b), EC (c), milk fat (d), protein (e) and SNF (f) percentage changes (mean \pm SEM) for the winter and summer groups of cows. Values with different superscripts $(a, b)$ at the same sampling time were significantly different. 
H. E. Colakoglu et al.: Glutathione peroxidase activity, milk composition and various parameters of subclinical mastitis

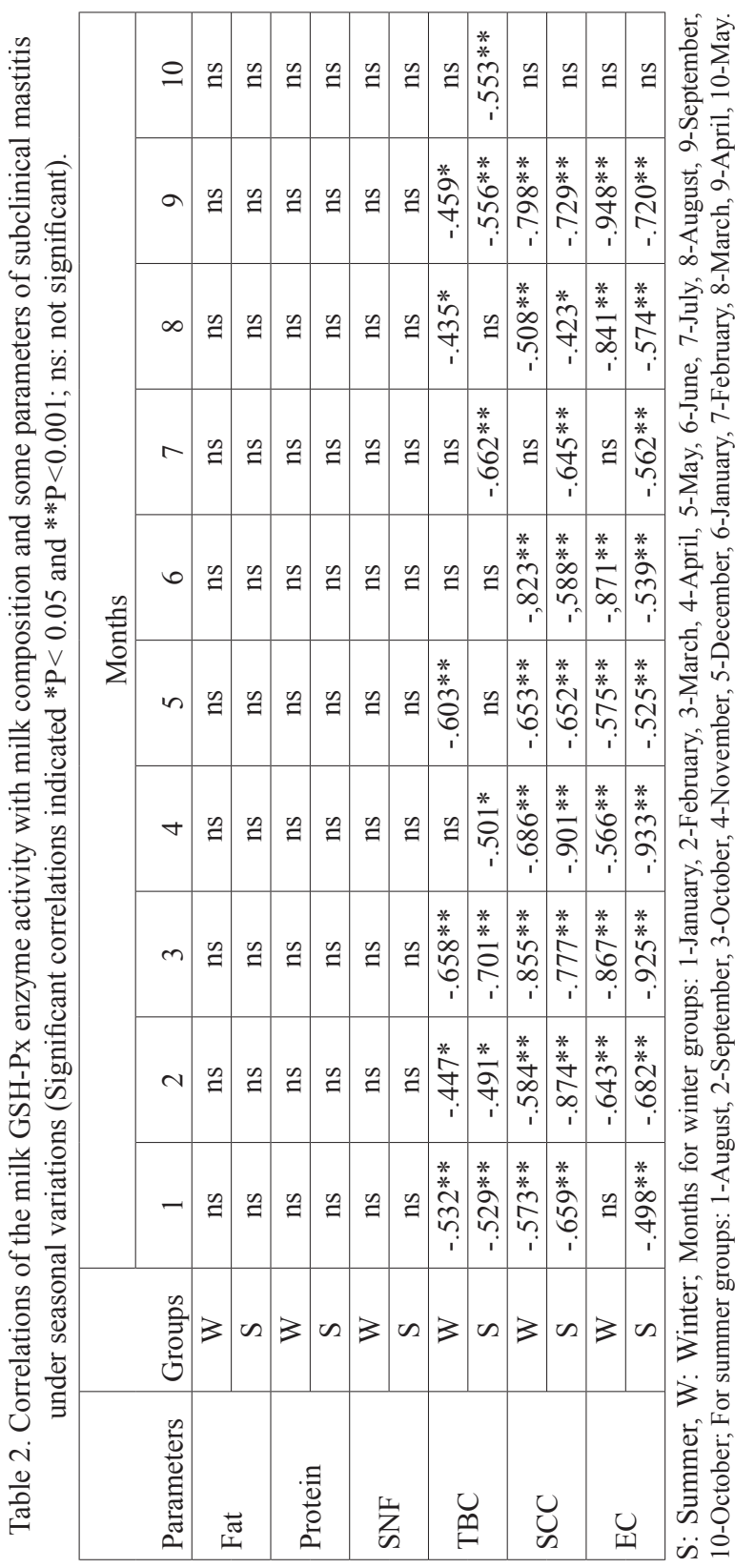

Vet. arhiv 87 (5), 557-570, 2017 
H. E. Colakoglu et al.: Glutathione peroxidase activity, milk composition and various parameters of subclinical mastitis

\section{Discussion}

Antioxidant enzymes in milk are valuable markers of oxidative status and udder health in dairy cows (ANDREI et al., 2011). A decrease in antioxidant enzymes has a negative effect on the immune system and phagocytic activity of cells, increasing the incidence of mastitis and puerperal disease (HAYAJNEH, 2014). GSH-Px is one of the principal enzymatic defence systems in controlling the free radicals induced by neutrophils (HAMED et al., 2008). However, GSH-Px deficiency leads to an increase in oxidative stress intensity (KANKOFER et al., 2010).

The changes in antioxidant activity in milk due to mastitis and seasonal variations remain controversial. The data obtained from the cited literature provide conflicting results (HAMED et al., 2008; MATEI et al., 2011; YANG et al., 2011). Some studies have investigated the activity of GSH-Px in bovine colostrum, milk and blood over a short period after calving, and in specific conditions such as clinical or subclinical mastitis (KANKOFER et al., 2010; ANDREI et al., 2011; ERISIR et al., 2011; KONVICNA et al., 2015). GSH-Px activity at different stages of lactation has also been determined (PILARCZYK et al., 2012). This study reflects the activity of GSH-Px during the whole period of lactation, with physiological variations.

Milk composition is influenced by many factors, such as genetics, environment, seasons and diseases. A significant decrease has been reported in milk fat and protein percentage during the summer months (PAVEL and GAVAN, 2011; BERTOCCHI et al., 2014). However, cows calving in winter had a higher fat and protein percentage than those calving in summer (BAUL et al., 2014). Likewise, summer SNF values were lower than in winter (HARRIS and BACHMAN, 2003). The present study was consistent with the reports previously described. We also observed a decrease in milk fat and protein percentage during the summer months.

Oxidative stress could affect the milk yield and milk quality, depending on the severity of inflammation (SAWA et al., 2007; HAYAJNEH, 2014). However, no information was obtained in previous studies regarding the relationship between milk GSH-Px and milk composition. In the current study, no correlation was found between milk composition and GSH-Px activity during lactation. We suggest that the main reason for the nonsignificant correlation between GSH-Px and milk composition might be the presence of healthy cows in the study.-

Somatic cell count has been used as a significant indicator in monitoring udder health and milk quality. Management, season, stage of lactation and parity are the factors that influence milk SCC levels. However, milk SCC has increased during the summer months (PAVEL and GAVAN, 2011; BERTOCCHI et al., 2014). In the present study, milk SCC increased significantly in summer months as was reported in previous studies. 
H. E. Colakoglu et al.: Glutathione peroxidase activity, milk composition and various parameters of subclinical mastitis

Data regarding the relationship between milk SCC and oxidant and antioxidant enzymes have been obtained in previous studies. A significant positive correlation between SCC and oxidant levels has been defined (ANDREI et al., 2009; ATAKISI et al., 2010) while a negative correlation was proven between SCC and antioxidants in blood and milk (ATAKISI et al., 2010; JOZWIK et al., 2012). Previous studies have shown a correlation between GSH-Px and SCC in milk. Findings in published reports are still controversial. ATAKISI et al. (2010) found no relationship between total antioxidant capacity and SCC in milk. HAMED et al. (2008) also defined a positive correlation between GSH-Px and SCC in total bulk milk. A positive correlation between GSH-Px and SCC was determined in cows with subclinical mastitis (ANDREI et al., 2011; MATEI et al., 2011). However, ERSKINE et al. (1987), HOGAN et al. (1993) reported a negative correlation between GSH-Px and SCC in milk. In contrast to previous research (HAMED et al., 2008; ANDREI et al., 2011; MATEI et al., 2011), this study reflects a significant negative correlation between GSHPx and SCC in milk. NDIWENI et al. (1991) has reported a negative correlation between the incidence of mastitis and GSH-Px activity in cows. However, antioxidant enzymes were used by neutrophils during an infection (ERISIR et al., 2011). SU et al. (2002) reported more infiltrated polymorphonuclear cells in milk with higher SCC, as well as increased oxidative reactions. A decrease in GSH-Px activity in mastitis, related to inflammation, has been defined (ATROSHI et al., 1987). In line with previous knowledge, in the study presented here, we suggest that a decrease in antioxidant level may be a result of the use of antioxidant enzymes by the neutrophils during inflammation. However, increased SCC in clinical or subclinical mastitis was associated with a concurrent decrease in antioxidant levels.

One study evaluated the relationships between climatic changes and TBC in milk. In the study, a significant increase in TBC was found during the summer months (BERTOCCHI et al., 2014). In the present study, a significant increase was also observed in TBC during the summer months.

Only a few studies are available concerning the relationship between TBC and GSHPx. The development of pathogenic bacteria in milk is associated with an increase in GSH-Px activity (MATEI et al., 2011). Therefore, a positive correlation between GSH-Px and TBC has been determined in milk with mastitis (ANDREI et al., 2011). In the current study, a significant negative correlation between TBC and GSH-Px levels has been observed. The level of enzyme activity depends on the type of bacteria (MATEI et al., 2011). ANDREI et al. (2011) reported that an antioxidant mechanism has been specified for each pathogen, and pathogens may be responsible for the production of milk GSHPx. The specific bacteria of $S$. intermedius, E. coli, B. cereus e.g. have been isolated in milk with mastitis (ANDREI et al., 2011). In the current study, we did not need to identify isolates because the SCC in all cows was under the limit of 400,000 cells $/ \mathrm{mL}$ previously described in the study by ANDREI et al. (2011). In the current study, we found a positive 
H. E. Colakoglu et al.: Glutathione peroxidase activity, milk composition and various parameters of subclinical mastitis

relationship between TBC and SCC. Therefore, increased TBC and SCC in milk reflect the increased use of antioxidants by neutrophils. The significant positive correlation between SCC and TBC in the current study supports this hypothesis. The results of the study also support the negative correlation between TBC and GSH-Px.

Electrical conductivity (EC) is one of the diagnostic methods for detection of subclinical mastitis. FIRK et al. (2002) reported that electrical conductivity was significantly higher in cows with a calving season between May and August than those with other calving seasons in the same year. In agreement with FIRK et al. (2002), in the current study we observed a significant increase in EC during the summer months.

No information was available regarding the relationship between milk GSH-Px and electrical conductivity in previous studies. This makes it difficult to compare the results of this study. Data obtained in this study showed a significant negative correlation between GSH-Px and EC in almost all lactation months. This would indicate that it is possible to foresee a decrease in GSH-Px levels in milk with a concurrent increase in EC.

In the present study, a significant negative correlation was detected between milk GSH-Px and the diagnostic methods for mastitis such as SCC, EC and TBC. The results obtained in this study clearly indicate a decrease in milk GSH-Px levels following intramammary infection.

Exposure to heat stress causes an oxidant/antioxidant imbalance (MEGAHED et al., 2008). However, heat stress causes a reduction in plasma antioxidant activity, increasing the production of free radicals and decreasing endogenous synthesis of antioxidants (HARMON et al., 1997; JOSHI et al., 2013). Some authors have pointed out the increased oxidant and decreased antioxidant activity during the summer months (BERNABUCCI et al., 2002; MEGAHED et al., 2008). Heat stressed cows had lower total antioxidants after calving during the summer than those calving in winter (TURK et al., 2015). In previous studies the relationships between antioxidant enzymes and heat stress were determined from blood samples (BERNABUCCI et al., 2002; MEGAHED et al., 2008; JOSHI et al., 2013). BERNABUCCI et al. (2002) also defined a decrease in blood GSH-Px activity during the summer months. Levels of blood SOD, GSH-Px and glutathione decreased in high ambient temperature during the summer (SAKATANI et al., 2012). However, no information regarding the relationship between milk GSH-Px and heat stress is present in the literature. In the study presented here, we investigated milk GSH-Px levels in cows with different calving seasons. Remarkable differences were found between the milk GSH-Px activity of cows with different seasons of calving during lactation. Both groups of cows, calving in winter and summer, had higher GSH-Px activity between January and May. Even though there was no long-term or severe heat stress during the study, the data obtained from the current study indicate that milk GSH-Px activity in cows during lactation could be influenced by seasonal variations (temperature and humidity). 
H. E. Colakoglu et al.: Glutathione peroxidase activity, milk composition and various parameters of subclinical mastitis

Stress is also known to cause an increase in glucocorticoid levels, and these were associated with a decrease in the function of the cells of the immune system. High levels of glucocorticoids have been reported to decrease blood glutathione and erythrocyte superoxide dismutase activity in rats (ORZECHOWSKI et al., 2000) and goats (ALILA JOHANSSON et al., 2003). BHAT et al. (2008) reported that the high temperature and humidity of summer increase neuroendocrine stress and lipid peroxidation, which contribute to reduced erythrocyte antioxidant response in rats. MEGAHED et al. (2008) reported a negative correlation between serum cortisol and SOD levels, a positive correlation between cortisol and oxidative stress in cows, particularly in summer. The cortisol levels were not evaluated in this study. However, in line with previous knowledge, it is possible to suggest that increased cortisol levels in high temperatures affected the milk antioxidant levels as well. Further research is needed to determine the relationship between serum cortisol and milk antioxidant activity under seasonal variations.

In conclusion, cows calving in winter in the area in question had higher GSH-Px activity than those calving in summer, especially in the first few months of lactation. In the current study, the milk composition from cows calving in different seasons is independent from the milk GSH-Px activity. The alteration of milk GSH-Px levels could be used as a diagnostic tool in monitoring udder health, because of its significant relationship with the parameters of subclinical mastitis.

\section{Conflict of interest}

None of the authors have any conflict of interest to declare in this work.

\section{Authors' contributions}

All authors participated in the design of the study and assisted in preparation of the manuscript. All authors have given final approval to the manuscript.

\section{References}

ABD ELLAH, M. R. (2013): Role of free radicals and antioxidants in mastitis. J. Adv. Vet. Res. 3, $1-7$.

ALILA JOHANSSON, A., L. ERIKSON, T. SOVERI, M. L. LAAKSO (2003): Serum cortisol levels in goats exhibit seasonal but not daily rhythmicity. Chronobiol. Int. 20, 65-79.

ANDREI, S., A. PINTEA, A. BUNEA, I. GROZA, L. BOGDAN, S. CIUPE, S. MATEI, D. CRAINIC (2009): Non-enzymatic antioxidants concentration and lipids peroxidation level in milk from cows with subclinical mastitis. Bulletin USAVM Veterinary Medicine 66, 196-201.

ANDREI, S., S. MATEI, N. FIT, C. CERNEA, S. CIUPE, S. BOGDAN, I. S. GROZA (2011): Glutathione peroxidase activity and its relationship with somatic cell count, number of colony forming units and protein content in subclinical mastitis cows milk. Roman. Biotechnol. Lett. $16,6209-6217$.

ATAKISI, O., H. ORAL, E. ATAKISI, O. MERHAN, S. M. PANCARCI, A. OZCAN, S. MARASLI, B. POLAT, A. COLAK, S. KAYA (2010): Subclinical mastitis causes alterations in nitric oxide, total oxidant and antioxidant capacity in cow milk. Res. Vet. Sci. 89, 10-13. 
H. E. Colakoglu et al.: Glutathione peroxidase activity, milk composition and various parameters of subclinical mastitis

ATROSHI, F., J. YOPPONEN, S. SANKARI, R. KANGASNIEMI, J. PARANTAINEN (1987): Possible roles of vitamin $\mathrm{E}$ and glutathione metabolism in bovine mastitis. Internat. J. Vit. Nutr. Res. 57, 37-43.

BAUL, S., L. T. CZISZTER, S. ACATINCAI, D. GAVOJDIAN, S. ERINA, A. MARCU, G. BUZAMAT, G. G. RADUCAN (2014): Seasonal influences on milk yield and composition dynamics during a normal lactation in dairy cows: Milk yield, fat and protein percentage. Anim. Sci. Biotechnol. 47, 260-265.

BERNABUCCI, U., B. RONCHI, N. LACETERA, A. NARDONE (2002): Markers of oxidative status in plasma and erythrocytes of transition dairy cows during hot season. J. Dairy Sci. 85, 2173-2179.

BERTOCCHI, L., A. VITALI, N. LACETERA, A. NARDONE, G. VARISCO, U. BERNABUCCI (2014): Seasonal variations in the composition of Holstein cow's milk and temperaturehumidity index relationship. Animal 8, 667-674.

BHAT, S., G. RAO, D. K. MURTHY, P. G. BHAT (2008): Seasonal variations in markers of stress and oxidative stress in rats. Indian J. Clin. Biochem. 23, 191-194.

CELI, P. (2011): Biomarkers of oxidative stress in ruminant medicine. Immunopharmacol. Immunotoxicol. 33, 233-240.

ERISIR, M., F. M. KANDEMIR, M. YUKSEL (2011): The effect of subclinical mastitis on MDA, GSH levels and GSH-Px, CAT activities in milk of cows. Firat University J. Health Sci. (Veterinary) 25, 67-70.

ERSKINE, R. J., R. J. EBERHART, L. J. HUTCHINSON, R. W. SCHOLZ (1987): Blood selenium concentrations and glutathione peroxidase activities in dairy herds with high and low somatic cell counts. J. Am. Vet. Med. Assoc. 190, 1417-1421.

FIRK, R., E. STAMER, W. JUNGE, J. KRIETER (2002): Systematic effects on activity, milk yield, milk flow rate and electrical conductivity. Arch. Tierz. Dummerstorf 45, 213-222.

FOX, P. F., A. L. KELLY (2006): Indigenous enzymes in milk, overview and historical aspects-part 2. Int. Dairy J. 16, 517-532.

HAMED, H., A. EL FEKI, A. GORGOURI (2008): Total and differential bulk cows milk somatic cell counts and their relation with antioxidant factors. C. R. Biologies 331, 144-151.

HARMON, R. J., M. LU, D. S. TRAMMEL, B. A. SMITH (1997): Influence of heat stress and calving on antioxidant activity in bovine blood. J. Dairy Sci. 80, 264 [abstract].

HARRIS, B., K. C. BACHMAN (2003): Nutritional and management factors affecting solids-notfat, acidity and freezing point of milk. Florida Cooperative Extension Service, Institute of Food and Agricultural Sciences, University of Florida, Gainesville, USA. pp. 1-5.

HAYAJNEH, F. M. F. (2014): Antioxidants in dairy cattle health and disease. Bulletin UASVM Veterinary Medicine 71, 104-109.

HOGAN, J. S., W. P. WEISS, K. L. SMITH (1993): Role of vitamin E and selenium in host defense against mastitis. J. Dairy Sci. 76, 2795-2803.

JOSHI, A., N. KATARIA, A. K. KATARIA, N. PANDEY, S. ASOPA, L. N. SANKHALA, R. PACHAURY, S. KHAN (2013): Stress related variations in serum vitamin E and C levels of Murrah buffaloes. J. Stress Physiol. Biochem. 9, 28-34. 
H. E. Colakoglu et al.: Glutathione peroxidase activity, milk composition and various parameters of subclinical mastitis

JOZWIK, A., N. STRZALKOWSKA, E. BAGNICKA, W. GRZYBEK, J. KRZYZEWSKI, E. POLAWSKA, A. KOLATAJ, J. O. HORBANCZUK (2012): Relationship between milk yield, stage of lactation and some blood serum metabolic parameters of dairy cows. Czech J. Anim. Sci. 57, 353-360.

KANKOFER, M., E. ALBERA, M. ROZANSKA-BOCZULA (2010): Activities of N-acetyl- $\beta$-Dglucosaminidase and glutathione peroxidase in bovine colostrum and milk. Czech J. Anim. Sci. 55, 488-495.

KONVICNA, J., M. VARGOVA, I. PULIKOVA, G. KOVAC, Z. KOSTECKA (2015): Oxidative stress and antioxidant status in dairy cows during prepartal and postpartal periods. Acta Vet. Brno 84, 133-140.

KUROKAWA, Y., R. YAMASHITA, M. OKITA, R. YOSHITOSHI, T. SUGINO, T. OBITSU, K. KAWAMURA (2016): A comparison of plasma glucose and oxidative status in lactating dairy cows in summer and autumn. Anim. Sci. J. 87, 1212-1217. doi: 10.1111/asj.12548.

MATEI, S. T., I. GROZA, L. BOGDAN, S. CIUPE, N. FIT, S. ANDREI (2011): Correlation between mastitis pathogenic bacteria and Glutathione peroxidase activity in cows milk. Bulletin UASVM, Vet. Med. 68, 221-225.

MEGAHED, G. A., M. M. ANWAR, S. I. WASFY, M. E. HAMMADEH (2008): Influence of heat stress on the cortisol and oxidant-antioxidants balance during oestrous phase in buffalo-cows (Bubalus bubalis): Thermo-protective role of antioxidant treatment. Reprod. Dom. Anim. 43, 672-677.

NDIWENI, N., T. R. FIELD, M. R. WILLIAMS, J. M. BOOTH, J. M. FINCH (1991): Studies on the incidence of clinical mastitis and blood levels of vitamin $\mathrm{E}$ and selenium in dairy herds in England. Vet. Rec. 129, 86-88.

ORZECHOWSKI, A., P. OSTASZEWSKI, A. BRODNICKA, J. WILCZAK, M. JANK, B. BALASINSKA, K. GRZELKOWSKA, T. PLOSZAJ, J. OLCZAK, A. MROWCZYNSKA (2000): Excess of glucocorticoids impairs whole-body antioxidant status in young rats-relation to the effect of dexamethasone in soleus muscle and spleen. Horm. Metab. Res. 32, 174-180.

PAGLIA, D. E., W. N. VALENTINE (1967): Studies on the quantitative and qualitative characterization of erythrocyte glutathione peroxidase. J. Lab. Clin. Med. 70, 158-169.

PAVEL, E. R., C. GAVAN (2011): Seasonal and milking-to-milking variations in cow milk fat, protein and somatic cell counts. Not. Sci. Biol. 3, 20-23.

PILARCZYK, B., D. JANKOWIAK, A. TOMZA-MARCINIAK, R. PILARCZYK, P. SABLIK, R. DROZD, A. TYLKOWSKA, M. SKOLMOWSKA (2012): Selenium concentration and glutathione peroxidase (GSH-Px) activity in serum of cows at different stages of lactation. Biol. Trace Elem. Res. 147, 91-96.

RAVAGNOLO, O., I. MISZTAL, G. HOOGENBOOM (2000): Genetic component of heat stress in dairy cattle, development of heat index function. J. Dairy Sci. 83, 2120-2125.

SAKATANI, M., A. Z. BALBOULA, K. YAMANAKA, M. TAKAHASHI (2012): Effect of summer heat enviroment on body temperature, estrous cycles and blood antioxidant levels in Japanese Black cow. Anim. Sci. J. 83, 394-402. 
H. E. Colakoglu et al.: Glutathione peroxidase activity, milk composition and various parameters of subclinical mastitis

SAWA, A., W. NEJA, M. BOGUCKI (2007): Relationships between cytological quality and composition of milk and the effect of some environmental factors on the frequency of recurrent mastitis in cows. J. Cent. Eur. Agri. 8, 295-300.

SORDILLO, L. M., S. L. AITKEN (2009): Impact of oxidative stress on the health and immune function of dairy cattle. Vet. Immunol. Immunopathol. 128, 104-109.

SU, W. J., C. J. CHANG, H. C. PEH, S. L. LEE, M. C. HUANG, X. ZHAO (2002): Apoptosis and oxidative stress of infiltrated neutrophils obtained from mammary glands of goats during various stages of lactation. Am. J. Vet. Res. 63, 241-246.

TURK, R., O. PODPECAN, J. MRKUN, Z. FLEGAR-MESTRIC, S. PERKOV, P. ZRIMSEK (2015): The effect of seasonal thermal stress on lipid mobilisation, antioxidant status and reproductive performance in dairy cows. Reprod. Dom. Anim. 50, 595-603.

YANG, F. L., X. S. LI (2015): Role of antioxidant vitamins and trace elements in mastitis in dairy cows. J. Adv. Vet. Anim. Res. 2, 1-9.

YANG, F. L., X. S. LI, B. X. HE, X. L. YANG, G. H. LI, P. LIU, Q. H. HUANG, X. M. PAN, J. LI (2011): Malondialdehyde level and some enzymatic activities in subclinical mastitis milk. Afr. J. Biotechnol. 10, 5534-5538.

COLAKOGLU, H. E., O. KUPLULU, M. R. VURAL, S. KUPLULU, M. O. YAZLIK, I. M. POLAT, B. OZ, U. KAYA, R. BAYRAMOGLU: Procjena povezanosti između aktivnosti glutation peroksidaze (GSH-Px) u mlijeku, sastava mlijeka i različitih pokazatelja supkliničkog mastitisa u uvjetima različitih sezona. Vet. arhiv 87, 557-570, 2017.

\section{SAŽETAK}

Ciljevi ovog istraživanja bili su, tijekom laktacje zdravih krava, procijeniti aktivnost glutation peroksidaze (GSH-Px) u mlijeku te odrediti različite druge sastojke (mliječnu masti, mliječne bjelančevine, bezmasnu suhu tvar, broj somatskih stanica (SCC), ukupan broj bakterija (TBC), električnu provodljivost (EC) i prikazati značajnost korelacija između aktivnosti GSH-Px, sastava mlijeka, SCC, TBC i EC u uvjetima različitih sezona. Krave oteljene u siječnju raspoređene su u zimsku skupinu $(\mathrm{n}=30)$, dok su ostale krave oteljene u kolovozu dodijeljene ljetnoj skupini $(\mathrm{n}=30)$. Tijekom laktacije, uzorci mlijeka su prikupljani jednom tjedno i na temelju toga za svaki pokazatelj utvrđene su prosječne mjesečne vrijednosti. Iako je aktivnost GSH-Px u mlijeku tijekom laktacije bila varijabilna, krave iz zimske skupine imale su u prvih pet mjesci značajno $(\mathrm{P}<0,001)$ višu aktivnost GSH-Px u odnosu na krave iz ljetne skupine. Međutim, između 6. i 10. mjeseca laktacije, aktivnost GSH-Px bila je znatno viša u ljetnoj skupini krava $(P<0,001)$. U obje skupine krava aktivnost GSH-Px bila je negativno povezana sa SCC, TBC i EC tijekom laktacije. Nije pronađena korelacija između aktivnosti GSH-Px i sastava mlijeka. Zaključno, na temelju njezinog odnosa s pokazateljima supkliničkog mastitisa, promjenjivost razine GSH-Px u mlijeku mogla bi se koristiti kao dijagnostički alat u praćenju zdravlja vimena. Nadalje, krave oteljene zimi imale su veću aktivnost GSH-Px od onih oteljenih ljeti, posebno tijekom prvih nekoliko mjeseci laktacije. Ovi rezultati upućuju na to da bi aktivnost GSH-Px u mlijeku krava tijekom laktacije mogla biti pod utjecajem sezonskih promjena.

Ključne riječi: krava, mlijeko, glutation peroksidaza, supklinički mastitis, sezona 